1. Optimasi Pola Tanam Hortikultura Di Desa Rantau Makmur Kecamatan Berbak Kabupaten Tanjung Jabung Timur

Ayu Arimbi Saninov, Zulkifli Alamsyah, Dan Melly Suryani

Hal $1-8$

2. Persepsi Petani Terhadap Usahatani Kedelai Di Kelurahan Simpang Kecamatan Berbak Kabupaten Tanjung Jabung Timur

Rani, Ratnawaty Siata, dan Idris Sardi

Hal 9- 18

3. Hubungan Perilaku Petani dengan Sistem Pelaksanaan Teknologi pada Usahatani Padi Sawah di Desa Sri Agung Kecamatan Batang Asam Kabupaten Tanjung Jabung Barat

Waridin, Arsyad Lubis dan Saidin Nainggolan

4. Kajian Diversifikasi Komoditas Sayur-Sayuran Dalam Rangka Peningkatan Pendapatan Petani Perkotaan Di Kecamatan Jambi Selatan Kota Jambi

Yoppy Wira Adie Setyantoro, Yanuar Fitri dan Elwamendry

Hal 28-34

5. Analisis Hubungan Faktor Sosial Ekonomi Dengan Partisipasi Anggota Kelompok tani Kelas Pemula Pada Usahatani Padi Sawah Di Kecamatan Sekernan Kabupaten Muaro Jambi

Elliana Ester Panjaitan, Dompak Napitupulu Dan Pera Nurfathiyah

Hal 35-43

6. Kajian Keragaan Pasar Tanaman Sayuran Dan Dampaknya Terhadap Hari Besar Keagamaan

Suharyon, Syafri Edi Dan Adri

7. Analisis Konsumsi Pangan Rumah Tangga Petani Karet Di Kecamatan Batin XXIV Kabupaten Batanghari

Ling Ling Susanti, Yusma Damayanti, Dan Dewi Sri Nurchaini

8. Peralihan Sistem Mata Pencaharian Hidup Orang Rimba (Studi Kasus Di Desa Bukit Suban Kecamatan Air Hitam Kabupaten Sarolangun)

Ningsih Susanti Rosyani, Idris Sardi

9. Sistem Pemasaran E-Commerce Produk Pertanian Berbasis Web Content Manajemen System

Tri Suratno

10. Perilaku Petani Terhadap Program Sekolah Lapang Iklim Dalam Usahatani Padi Sawah (Kasus Di Desa Tebing Tinggi Kecamatan Siulak Kabupaten Kerinci Dan Desa Koto Panap Kecamatan Tanah Kampung Kota Sungai Penuh)

Dela Novela, Suandi , Dan Aulia Farida

Hal 80-87

11. Analisis Elastisitas Transmisi Harga Bahan Olah Karet Pada Saluran Pemasaran Koperasi Dan Bukan Koperasi Di Kecamatan Mestong Kabupaten Muaro Jambi

Harry Marhayadhy. N' A. Rahman , Adlaida Malik

Hal 88-98

12. Analisis Permintaan Dan Penawaran Beras Di Propinsi Jambi

Edison Dan Pera Nurfathiyah

Hal 44-49

Hal 50-60

Hal 61-71

Hal 72-79

Hal 99-105

Volume 15. No 2

Juli - Desember 2012
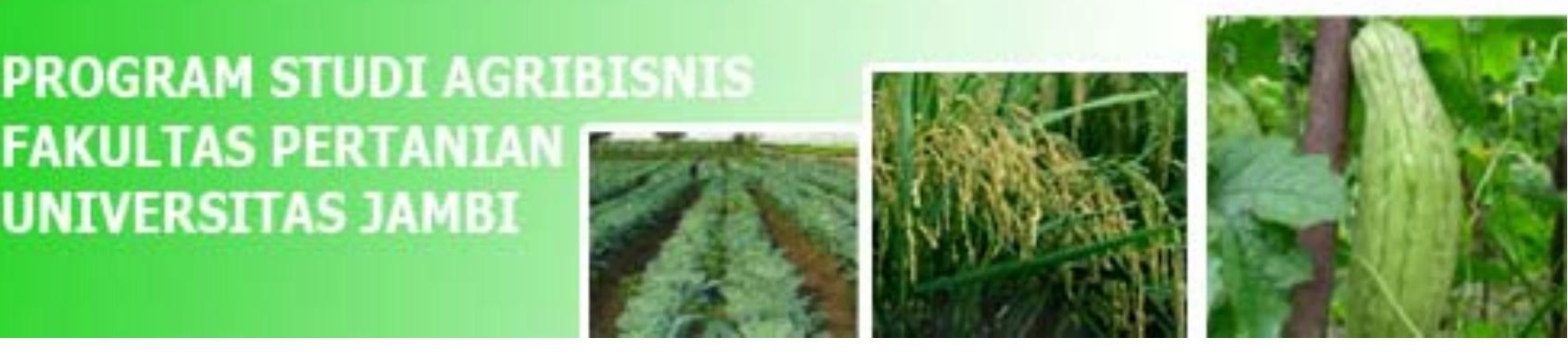


\title{
OPTIMASI POLA TANAM HORTIKULTURA DI DESA RANTAU MAKMUR KECAMATAN BERBAK KABUPATEN TANJUNG JABUNG TIMUR
}

\author{
Ayu Arimbi Saninov ${ }^{1),}$ Zulkifli Alamsyah $^{2)}$ dan Melly Suryani ${ }^{2)}$ \\ 1) Alumni Program Studi Agribisnis Fakultas Pertanian Universitas Jambi, \\ 2) Staf Pengajar Program Studi Agribisnis Fakultas Pertanian Universitas Jambi \\ Email: arimbi_ayu@yahoo.com
}

\begin{abstract}
Abstrak
Penelitian ini bertujuan untuk (1) mempelajari penggunaan input, biaya dan pendapatan usahatani, (2) menganalisis pola tanam yang optimal, dan (3) menguji peningkatan pendapatan usahatani dari penerapan pola usahatani yang optimal pada usahatani hortikultura di Desa Rantau Makmur Kecamatan Berbak Kabupaten Tanjung Jabung Timur. Metode analisis yang digunakan adalah analisis biaya dan pendapatan usahatani, optimasi pola tanam menggunakan model linear programming dan uji statistik-t untuk beda dua rata-rata. Dari hasil penelitian dapat disimpulkan bahwa terdapat berbagai variasi pola tanam tanaman hortikultura oleh petani dengan pendapatan rata-rata Rp. 30.071 .087 per hektar per periode tanam. Berdasarkan hasil optimasi diperoleh pola tanam yang optimal untuk satu periode tanam adalah pengusahaan tanaman cabai 0,71 hektar dan kacang panjang 0,29 hektar. Dengan pola tanam yang optimal tersebut diperoleh peningkatan pendapatan secara signifikan sebesar 7,3 persen per periode tanam.
\end{abstract}

Kata Kunci : Optimasi, Pola Tanam, Linear Programming

\begin{abstract}
This study aims to (1) study the use of inputs, costs and farm income, (2) analyze the optimal cropping patterns, and (3) test the application of increased farm income from farming on the optimal pattern of horticultural farming in the village of Rantau Makmur subdistrict Berbak Tanjung Jabung district. The analytical method used was analysis of the costs and farm income, cropping pattern optimization using linear programming models and statistical t-test for two different average. From the results of this study concluded that there are different variations of horticultural cropping by farmers with an average income of $\mathrm{Rp}$. $30,071,087$ per hectare per year. Based on the optimization results obtained that the optimum cropping pattern for the planting period was planting chili and beans 0.71 hectare and 0.29 hectare respectively. With the optimal cropping patterns there is a significant increase in farm income of 7.3 percent per planting period.
\end{abstract}

Keywords: Optimization, Planting Pattern, Linear Programming

\section{PENDAHULUAN}

Pertanian merupakan sektor strategis dalam hampir setiap ekonomi negara berkembang. Komoditas pertanian merupakan komoditas yang sangat penting dan strategis karena sebagian besar jenis komoditi pertanian merupakan kebutuhan pokok manusia. Dalam sektor pertanian komoditas hortikultura merupakan komoditas potensial yang mempunyai nilai ekonomi dan permintaan pasar yang tinggi.

Desa Rantau Makmur merupakan salah satu daerah penghasil hortikultura, hortikultura khususnya sayuran diusahakan pada saat kondisi air sedang surut yaitu pada bulan Mei-November. Keberagaman komoditi hortikultura yang ditanam oleh petani mengakibatkan timbulnya variasi pola tanam.

Usahatani merupakan suatu kegiatan mengusahakan dan mengkoordinir faktor-faktor produksi berupa lahan dan alam sekitarnya sebagai modal sehingga memberikan manfaat sebaikbaiknya (Suratiyah, 2009). Salah satu permasalahan yang dihadapi oleh petani dalam 
mengembangkan usahataninya adalah tidak adanya perencanaan yang tegas dalam pengelolaan usahatani. Sebagian besar petani tidak dapat mengalokasikan penggunaan sumberdaya yang dimilikinya secara efektif dan efesien, sehingga pendapatan yang diperoleh petani dari usahataninya tidak maksimal.

Menurut Hernanto, (1996) dalam usahatani terdapat empat unsur pokok yang selalu ada, unsur tersebut juga dikenal dengan istilah faktor produksi yang terdiri dari tanah, tenaga kerja, modal dan pengelola. Selanjutnya faktor lahan, tenaga kerja dan modal pada umumnya menjadi faktor pembatas bagi petani dalam pencapaian keuntungan maksimum. Pemakain input faktor-faktor produksi usahatani berpengaruh pada produksi usahatani. Input faktor-faktor produksi antara lain luas lahan, tenaga kerja, saprodi, alat-alat pertanian dan modal. Selanjutnya produksi usahatani akan mempengaruhi penerimaan petani dan akan berpengaruh kepada pendapatan petani.

Pola tanam adalah usaha yang dilakukan dengan melaksanakan penanaman pada sebidang lahan dengan mengatur susunan tata letak dari tanaman dan tata urutan tanaman selama periode waktu tertentu, termasuk masa pengolahan tanah dan masa tidak ditanami selama periode tertentu (Setjanata, 1983). .Penentuan pola tanam optimal merupakan salah satu perencanaan usaha tani yang dapat dilakukan agar rendahnya pendapatan petani dapat diatasi. Pengaturan pola tanam melibatkan pengalokasian sumberdaya pembatas dalam faktor-faktor produksi. Sumberdaya yang menjadi pembatas dalam pengaturan pola tanam adalah luas lahan, tenaga kerja, modal, dan biaya.

Dalam salah satu penelitian terdahulu disimpulkan bahwa pendapatan petani dapat ditingkatkan melalui proses optimasi (Setiawati, 2006). Optimasi dapat dilakukan dengan menggunakan Linear programming (LP). Linear programming (LP) merupakan metode matematika dalam mengalokasikan sumberdaya yang langka dalam mencapai tujuan tunggal seperti memaksimumkan keuntungan atau meminimumkan biaya (Mulyono, 2007). Optimasi pola tanam diharapkan dapat meningkatkan pendapatan yang maksimum bagi petani.

Tujuan pola tanam optimal yaitu keuntungan maksimal mempunyai nilai kuantitatif sehingga dalam perencanaan pola tanam optimal tersebut diperlukan pendekatan secara kuantitatif dengan pertimbangan bahwa pendekatan kuantitatif selalu didasarkan pada seperangkat analisis empiris yang terukur sifatnya, sebaliknya pendekatan kualitatif didasarkan pada pertimbangan judgement pembuat keputusan (Soekartawi, 1995).

Penelitian ini bertujuan untuk mengetahui (1) berapa penggunaan input, biaya dan pendapatan usahatani hortikultura dari penerapan pola tanam yang diusahakan petani, dan (2) pola tanam yang optimal yang dapat memberikan pendapatan maksimum bagi petani, dan (3) apakah pola tanam yang optimal tersebut memberikan peningkatan pendapatan yang signifikan

\section{METODE PENELITIAN}

Penelitian ini dilaksanakan di Desa Rantau Makmur dengan pertimbangan bahwa di Desa Rantau Makmur merupakan salah satu penghasil komoditi hortikultura di Kecamatan Berbak Kabupaten Tanjung Jabung Timur dan para petani komoditi hortikultura melakukan pola tanam yang sangat bervariasi. Jumlah sampel yang digunakan, dengan menggunakan kaidah slovin dalam Ridwan (2009) sebanyak 47 orang dan penentuan sampel dilakukan secara random.

Pada daerah penelitian yang merupakan daerah pasang surut, penanaman tanaman hortikultura di lakukan dari bulan Mei - Oktober. Hal tersebut di sebabkan pada bulan Mei - Oktober air sedang surut sehingga lahan tidak tergenang air, sehingga cocok untuk ditanami tanaman hortikultura. Berdasarkan kondisi tersebut metode analisis optimasi dengan linear programming 
menggunakan model umum yang dibentuk dari pola tanam yang diusahakan oleh petani di daerah penelitian. Model tersebut dijabarkan sebagai berikut :

\section{Fungsi Tujuan :}

$\operatorname{Max} Z=\mathrm{c}_{1} \mathrm{X}_{1}+\mathrm{c}_{2} \mathrm{X}_{2}+\mathrm{c}_{3} \mathrm{X}_{3}+\mathrm{c}_{4} \mathrm{X}_{4}+\mathrm{c}_{5} \mathrm{X}_{5}+\mathrm{c}_{6} \mathrm{X}_{6}$

\section{Fungsi Kendala}

$\begin{array}{lll}\text { Lahan } & : X_{1}+X_{2}+X_{3}+X_{4}+X_{5}+X_{6} & \leq b_{1} \\ \text { T.K Mei } & : a_{1.1} X_{1}+a_{1.2} X_{2}+a_{1.3} X_{3}+a_{1.4} X_{4}+a_{1.5} X_{5}+a_{1.6} X_{6} & \leq b_{2} \\ \text { T.K Juni } & : a_{2.1} X_{1}+a_{2.2} X_{2}+a_{2.3} X_{3}+a_{2.4} X_{4}+a_{2.5} X_{5}+a_{2.6} X_{6} & \leq b_{3} \\ \text { T.K Juli } & : a_{3.1} X_{1}+a_{3.2} X_{2}+a_{3.3} X_{3}+a_{3.4} X_{4}+a_{3.5} X_{5}+a_{3.6} X_{6} & \leq b_{4} \\ \text { T.K Agust } & : a_{4.1} X_{1}+a_{4.2} X_{2}+a_{4.3} X_{3}+a_{4.4} X_{4}+a_{4.5} X_{5}+a_{4.6} X_{6} & \leq b_{5} \\ \text { T.K Sept } & : a_{5.1} X_{1}+a_{5.3} X_{3}+a_{5.5} X_{5} & \leq b_{6} \\ \text { T.K Okt } & : a_{6.3} X_{3} & \leq b_{7} \\ \text { Modal } & : a_{7.1} X_{1}+a_{7.2} X_{2}+a_{7.3} X_{3}+a_{7.4} X_{4}+a_{7.5} X_{5}+a_{7.6} X_{6} \leq b_{8}\end{array}$

$Z$ = fungsi tujuan yang memaksimumkan pendapatan petani (Rp)

$\mathrm{C}=$ pendapatan usahatani $(\mathrm{Rp} / \mathrm{Ha})$

TK = Tenaga kerja

$\mathrm{X}_{1}=$ luas lahan yang ditanami Terong $(\mathrm{Ha})$

$X_{2}=$ luas lahan yang ditanami Ketimun $(\mathrm{Ha})$

$\mathrm{X}_{3}=$ luas lahan yang ditanami Cabai $(\mathrm{Ha})$

$\mathrm{X}_{4}=$ luas lahan yang ditanami Gambas $(\mathrm{Ha})$

$\mathrm{X}_{5}=$ luas lahan yang ditanami Kacang Panjang $(\mathrm{Ha})$

$\mathrm{X}_{6}=$ luas lahan yang ditanami Pare $(\mathrm{Ha})$

$\mathrm{a}_{1.1} \ldots, \mathrm{a}_{1.6}=$ curahan tenaga kerja pada bulan mei (TKSP)

$\mathrm{a}_{2.1} \ldots, \mathrm{a}_{2.6} \quad=$ curahan tenaga kerja pada bulan juni (TKSP)

$a_{3.1} \ldots, a_{3.6}=$ curahan tenaga kerja pada bulan juli (TKSP)

$\mathrm{a}_{4.1} \ldots, \mathrm{a}_{4.6} \quad=$ curahan tenaga kerja pada bulan agustus (TKSP)

$a_{5.1} \ldots, a_{5.6}=$ curahan tenaga kerja pada bulan september (TKSP)

$a_{6.1} \ldots, a_{6.6}=$ curahan tenaga kerja pada bulan oktober (TKSP)

$a_{7.1} \ldots, a_{7.6}=$ modal usahatani untuk setiap cabang usahatani (Rp.)

$\mathrm{b}_{1}=$ ketersediaan sumberdaya lahan petani $(\mathrm{Ha})$

$\mathrm{b}_{2}=$ ketersediaan sumberdaya tenaga kerja bulan mei (TKSP)

$\mathrm{b}_{3}=$ ketersediaan sumberdaya tenaga kerja bulan juni (TKSP)

$\mathrm{b}_{4}=$ ketersediaan sumberdaya tenaga kerja bulan juli (TKSP)

$b_{5}=$ ketersediaan sumberdaya tenaga kerja bulan agustus (TKSP)

$\mathrm{b}_{6}=$ ketersediaan sumberdaya tenaga kerja bulan september (TKSP)

$b_{7}=$ ketersediaan sumberdaya tenaga kerja bulan oktober (TKSP)

$\mathrm{b}_{8}=$ ketersediaan sumberdaya modal usahatani (Rp.)

Pendapatan usahatani dianalisis menggunakan konsep biaya dan pendapatan dengan formula $\pi=T R-T C$. Dimana $\pi$ adalah pendapatan usahatani, TR adalah total penerimaan usahatani dan TC adalah total biaya usahatani. Sedangkan untuk menguji apakah terjadi peningkatan 
pendapatan dengan penerapan pola tanam yang optimal diginajan uji-t beda dua rata-rata untuk menguji hipotesis sebagai berikut:

$$
\begin{aligned}
& \mathrm{H}_{0}: \mu_{1}-\mu_{2}=0 \\
& \mathrm{H}_{0}: \mu_{1}-\mu_{2}<0
\end{aligned}
$$

Dengan alat uji sebagai berikut :

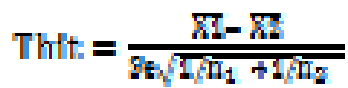

$$
\begin{aligned}
& S \varepsilon^{2}=\frac{\left(n_{1}-1\right) g_{1}^{2}-\left(n_{r}-1\right) g_{\gamma}^{2}}{\left(n_{1}+n_{2}\right)-2} \\
& E_{1}^{2}=\frac{1}{n_{1}-1} \times \Sigma\left[\left(X_{1}-Z\right)^{2}\right] \\
& s_{2}{ }^{2}=\frac{1}{n_{2}-1} x \Sigma\left[\left(\alpha_{2}-\Sigma^{2}\right)^{2}\right]
\end{aligned}
$$

Dimana :

$X_{1} \& X_{2}=$ rata - rata pendapatan usahatani sebelum dan setelah optimasi

$\mathrm{n}_{1} \& \mathrm{n}_{2}=$ jumlah sampel sebelum dan sesudah optimasi

$S_{1}^{2} \quad=$ varians pendapatan usahatani setelah optimasi

$S_{2}^{2} \quad=$ varians pendapatan usahatani sebelum optimasi

Kaidah pengambilan keputusan adalah :

Tolak Ho bila t-hit $>\mathrm{t}-\mathrm{tab}\left(\mathrm{t} \alpha: d b=\mathrm{n}_{1}+\mathrm{n}_{2}-2\right) ; \alpha=0,05$

Terima Ho bila t-hit $\leq \mathrm{t}-\mathrm{tab}\left(\mathrm{t} \alpha: d b=\mathrm{n}_{1}+\mathrm{n}_{2}-2\right) ; \alpha=0,05$

\section{HASIL DAN PEMBAHASAN}

\section{Pendapatan dan Ketersediaan Sumber Daya}

Rata-rata luas lahan yang dimiliki petani di daerah penelitian adalah seluas $1 \mathrm{Ha}$, sehingga dalam perumusan model linear programming, data yang diperoleh dikonversikan kedalam satuan

\begin{tabular}{|c|c|c|c|c|c|c|c|c|}
\hline \multirow{2}{*}{ No } & \multirow{2}{*}{ Uraian } & \multicolumn{6}{|c|}{ Cabang Usahatani } & \multirow{2}{*}{ Ketersediaan } \\
\hline & & Terong & Ketimun & Cabai & Gambas & K. pjg & Pare & \\
\hline 1 & Pendapatan & $\begin{array}{r}12.287 \\
958,33\end{array}$ & $\begin{array}{r}10.939 \\
543,33\end{array}$ & $\begin{array}{r}31.093 . \\
277\end{array}$ & $\begin{array}{r}11.858 \\
589,06\end{array}$ & $\begin{array}{r}35.115 . \\
058,33\end{array}$ & $\begin{array}{l}18.237 \\
283,33\end{array}$ & \\
\hline \multirow[t]{7}{*}{2} & \multicolumn{8}{|c|}{ Tenaga Kerja (TKSP) } \\
\hline & Mei & 92,56 & 280,61 & 333,33 & 220,69 & 152,03 & 125,42 & 336 \\
\hline & Juni & 68,54 & 304,99 & 151,8 & 141,1 & 120,25 & 98,55 & 336 \\
\hline & Juli & 95,62 & 335,97 & 151,8 & 253,16 & 220,46 & 162,89 & 336 \\
\hline & Agustus & 128,98 & 213,73 & 212,72 & 209,31 & 221,26 & 121,08 & 336 \\
\hline & September & 62,46 & 0 & 228,67 & 0 & 94,65 & 0 & 336 \\
\hline & Oktober & 0 & 0 & 226,83 & 0 & 0 & 0 & 336 \\
\hline \multirow{2}{*}{3} & \multirow{2}{*}{ Modal } & 3.212 .0 & 3.193 .7 & 3.037 .9 & 3.703 .9 & 5.218 .2 & 4.637 .7 & 446.81 \\
\hline & & 41,67 & 90 & 82 & 10,94 & 75 & 16,67 & $5 / 5 / 446,81$ \\
\hline
\end{tabular}
Ha. Hasil tabulasi data mengenai Rata-rata pendapatan dan kebutuhan sumber daya per hektar serta ketersedian sumber daya pada masing-masing usahatani dapat disajikan pada Tabel 1.

Tabel 1. Rata-rata Pendapatan dan Kebutuhan Sumber Daya Per Hektar serta Ketersediaan Sumber Daya pada Masing-masing Usahatani

Sumber : Hasil Olahan Data 


\section{Konstruksi Model Optimasi}

Berdasarkan data pada Tabel 1 maka di rumuskan model program linear yang selanjutnya akan digunakan dalam penelitian ini. Dalam pembuatan model, sumberdaya yang digunakan sebagai kendala dan jumlah ketersediaannya disesuaikan dengan kondisi riil petani selama peeriode musim tanam. Penggunaan tenaga kerja yang terpakai dihitung berdasarkan penggunaan curahan tenaga kerja dalam keluarga pada setiap bulannya. Perhitungan modal diperoleh dari total biaya yang terpakai selama proses produksi. Nilai sebelah kanan modal didapat dari potensi modal yang dimiliki yang dapat berasal dari tabungan, perhiasan dan pendapatan non usahatani hortikultura dan dialokasikan oleh petani untuk usahatani hortikultura.

Pada awalnya daya serap pasar terhadap kacang panjang tidak jadikan sebagai faktor pembatas. Akan tetapi setelah dilakukan optimasi dengan menggunakan program Linear Interactive Discrete Optimizer (LINDO) diperoleh hasil bahwa pola tanam yang sebaiknya dilakukan adalah monokultur kacang panjang. Apabila semua petani mengusahakan kacang panjang maka akan terjadi kelebihan supply (ketersediaan), sehingga dilakukan pembatasan terhadap luas lahan maksimum yang dapat ditanami kacang panjang melalui pertimbangan daya serap pasar terhadap kacang panjang.

Penentuan daya serap pasar dihitung melalui perkalian konsumsi perkapita kacang panjang pada masa panen dengan jumlah penduduk didaerah penelitian dan dikonversi kedalam satuan hektar. Sehingga diperoleh luas lahan maksimum untuk ditanami kacang panjang yang selanjutnya dijadikan sebagai nilai sebelah kanan untuk model daya serap pasar terhadap kacang panjang.

Penentuan daya serap pasar dihitung melalui perkalian konsumsi perkapita kacang panjang pada masa panen dengan jumlah penduduk didaerah penelitian dan dikonversi kedalam satuan hektar. Sehingga diperoleh luas lahan maksimum untuk ditanami kacang panjang yang selanjutnya dijadikan sebagai nilai sebelah kanan untuk model daya serap pasar terhadap kacang panjang.

Dari penjelasan diatas maka dapat dirangkum keseluruhan model program linear tersebut seperti dibawah ini.

\section{Fungsi Tujuan: Memaksimumkan Pendapatan ( $\mathrm{Z}$ )}

$$
\begin{aligned}
Z= & 12287958.33 \times 1+10939543.33 \times 2+31093277 \times 3+11858589.06 \times 4+35115058.33 \times 5+ \\
& 18237283.33 \times 6
\end{aligned}
$$

\begin{tabular}{|c|c|c|}
\hline Lahan & $X 1+X 2+X 3+X 4+X 5+X 6$ & $\leq 1$ \\
\hline T.K Mei & $92.56 \times 1+333.33 \times 3+125.42 \times 6$ & $\leq 336$ \\
\hline T.K Juni & $68.54 \times 1+280.61 \times 2+151.80 \times 3+152.03 \times 5+98.55 \times 6$ & $\leq 336$ \\
\hline T.K Juli & $95.62 \times 1+304.99 \times 2+151.80 \times 3+220.69 \times 4+120.25 \times 5+162.89 \times 6$ & $\leq 336$ \\
\hline T.K Agus & $128.98 \times 1+335.97 \times 2+212.72 \times 3+141.10 \times 4+220.46 \times 5+121.08 \times 6$ & $\leq 336$ \\
\hline T.K Sept & $62.46 \times 1+213.73 \times 2+228.67 X 3+253.16 X 4+221.26 \times 5$ & $\leq 336$ \\
\hline T.K Okt & $226.83 \times 3+209.31 \times 4+94.65 \times 5$ & $\leq 336$ \\
\hline \multirow[t]{2}{*}{ Modal } & $3212.04 \times 1+3193.79 \times 2+3037.98 \times 3+370.39 \times 4+5218.27 \times 5$ & \\
\hline & $+4617.72 \times 6$ & $\leq 5757.45$ \\
\hline \multirow{2}{*}{\multicolumn{2}{|c|}{$\begin{array}{l}\text { Daya Serap Pasar Terhadap Kacang Panjang: } \\
\text { Kendala non negative }\end{array}$}} & $\leq 0.29$ \\
\hline & & $\geq 0$ \\
\hline
\end{tabular}

\section{Dengan Kendala :}

Keofisien fungsi tujuan diperoleh dari pendapatan rata-rata per hektar untuk setiap cabang usahatani. Koefisien kendala lahan di dapat dari rata-rata luas lahan yang di miliki petani. Keofisien kendala tenaga kerja diperoleh dari pengunaan tenaga kerja yang terpakai pada setiap bulannya. 
Sedangkan koefisien kendala modal di dapat dari perhitungan modal yang digunakan pada setiap cabang usahatani.

\section{Hasil Optimasi}

Selanjutnya model program linear diatas diolah dengan menggunakan program LINDO. Dari hasil, optimasi tersebut diperoleh Adapun hasil dari optimasi dapat dilihat pada Tabel 2.

Tabel 2. Hasil Optimasi Pola Tanam Usahatani Hortikultura

\begin{tabular}{crr}
\hline & Nilai Fungsi Tujuan: 32.259 .590 & \\
\hline Variabel & Nilai & Reduced Cost \\
\hline X1 & 0 & 18.805 .318 \\
X2 & 0 & 20.153 .732 \\
X4 & 0,71 & 0 \\
X5 & 0 & 19.234 .688 \\
X6 & 0,29 & 0 \\
\hline Kendala & 0 & 12.855 .992 \\
\hline Lahan & Plack or Surplus & \\
TK Bulan Mei & 0,00 & Dual Prices \\
TK Bulan Juni & 99,33 & 31.093 .276 \\
TK Bulan Juli & 184,13 & 0,00 \\
TK Bulan Agustus & 193,35 & 0,00 \\
TK Bulan September & 121,04 & 0,00 \\
TK Bulan Oktober & 109,48 & 0,00 \\
Modal & 147,50 & 0,00 \\
Daya Serap Pasar & 2.087 .180 & 0,00 \\
Kacang Panjang & & 0,00 \\
\hline Sumber: Hasil Olahan Data $L I N D O$ & 0,00 & 4.021 .784 \\
\end{tabular}

Berdasarkan hasil optimasi diatas, diperoleh solusi bahwa untuk memaksimumkan pendapatan maka yang menguntungkan untuk diusahakan di daerah penelitian adalah komoditi cabai seluas 0,71 $\mathrm{Ha}$ dan kacang panjang seluas 0,29 $\mathrm{Ha}$. Keuntungan yang akan diperoleh adalah sebesar Rp. 32.259.590

Lahan menjadi faktor pembatas dalam usahatani hortikultura karena nilai dual Prices atau harga bayangan yang memiliki arti yaitu nilai sumberdaya bagi petani sebesar 31.093.276. Artinya bila petani menambah sumberdaya lahan sebesar 1 Ha maka akan memberikan tambahan pendapatan sebesar Rp. 31.093.276. Akan tetapi besar penambahan luas lahan akan sangat dipengaruhi oleh analisis kepekaan (Sensitivity Analisis).

Daya serap pasar terhadap kacang panjang menjadi faktor pembatas dalam usahatani hortikultura karena nilai harga bayangannya sebesar 4.021.784. Hal ini berarti bila terjadi pertambahan penduduk atau permintaan kacang panjang meningkat pada hari-hari besar keagamaan hingga permintaan mencapai $2.339,33 \mathrm{Kg}$, sehingga menyebabkan petani harus menambah sumber daya lahan sebesar 0.29 Ha maka akan memberikan tambahan pendapatan sebesar Rp. 4.021.784. 
Tenaga kerja bukan merupakan faktor pembatas dalam usahatani hortikultura karena nilai harga bayangannya adalah nol (0) dan masih bersisa setiap bulannya. Kelebihan sumber daya tenaga kerja sebesar 99,33 TKSP pada bulan Mei, 184,13 TKSP pada bulan Juni, 193,35 TKSP pada bulan Juli, 121,04 TKSP pada bulan Agustus, 109,48 TKSP pada bulan September dan 147,50 TKSP pada bulan Oktober.

Modal juga tidak menjadi faktor pembatas dalam usahatani hortikultura karena nilai harga bayangannya adalah nol (0) dan masih adanya kelebihan modal. Kelebihan sumberdaya modal adalah sebesar Rp. 2.087.180.

Setelah dilakukan proses optimasi maka dilanjutkan dengan analisis kepekaan (Sensitivity Analisis) yang digunakan untuk mengetahui sampai seberapa jauh batas-batas perubahan masih bisa dilakukan sehingga hasil optimasi tidak berubah atau dipertahankan. Adapun hasil analisis kepekaan adalah sebagai pada Tabel 3.Nilai Allowable Increase komoditi cabai sama dengan nilai Allowable Decrease komoditi kacang panjang, artinya $b$ ila permintaan komoditi cabai meningkat hingga menyebabkan penambahan pendapatan mencapai Rp. 4.021 .784 atau harga jual kacang panjang menurun sehingga menyebabkan pendapatan menurun mencapai Rp. 4.021 .784 maka ada kemungkinan solusi yang dihasilkan adalah mengusahakan cabai seluruhnya. Hal ini dikarenakan komoditi cabai dan kacang panjang memiliki tingkat pendapatan yang bersaing. Bila pendapatan kacang panjang meningkat akibat peningkatan harga jual kacang panjang hingga tidak terbatas maka tidak akan mengubah solusi yaitu mengusahakan cabai 0,71 $\mathrm{Ha}$ dan kacang panjang 0,29 $\mathrm{Ha}$. Hal ini dikarenakan adanya pembatasan pada pengusahaan kacang panjang berdasarkan daya serap pasar.

Penggunaan tenaga kerja optimal adalah sebesar 236,67 TKSP pada bulan Mei, 151,87 TKSP pada bulan Juni, 142,65 TKSP pada bulan Juli, 214,96 TKSP pada bulan Agustus, 226,52 TKSP pada bulan September, dan 188,50 TKSP pada bulan Oktober. Penggunaan modal yang optimal adalah sebesar Rp. 3.670.266,81. Sehingga petani di daerah penelitian juga dapat melakukan penghematan pada sumberdaya modal sebesar Rp.2.087.180. Melalui penggunaan sumberdaya secara efisien maka kelebihan sumberdaya dapat dialokasikan petani untuk kegiatan lainnya yang dapat memberikan tambahan pendapatan bagi petani.

\section{Peningkatan Pendapatan dengan Penerapan Pola Optimal}

Dari penerapan pola tanam optimal tersebut akan memberikan pendapatan maksimum bagi petani. Berdasarkan hasil penelitian terjadi peningkatan pendapatan setelah optimasi bila dibandingkan dengan pendapatan sebelum optimasi. Pendapatan setelah optimasi adalah sebesar Rp.32.259.590 sedangkan pendapatan sebelum optimasi sebesar Rp.30.071.087.

Berdasarkan hasil pengujian t-hitung terhadap pendapatan petani setelah optimasi dan pendapatan petani setelah optmasi diperoleh nilai t-hitung 2,3. Nilai t-hitung lebih besar dari nilai ttabel $(1,661)$. Menurut kriteria uji t, jika t-hitung $>$ t-tabel pada taraf nyata 5 persen $(\alpha=0,05)$ maka tolak HO . Dengan demikian, dapat disimpulkan bahwa terdapat peningkatan pendapatan yang signifikan dari penerapan pola tanam hortikultura yang optimal di daerah penelitian sebesar 7.3 persen per musim tanam.

\section{KESIMPULAN DAN SARAN}

Pengusahaan tanaman hotikultura di daerah penelitian dilaksanakan dengan berbagai veriasi pola tanam dan dengan skala usaha yang relative kecil sehingga kurang menguntungkan. Hasil penelitian penelitian menunjukkan bahwa peningkatan pendapatan petani dapat ditingkatkan dengan menerapkan pola tanam yang optimal serta dengan memperhatikan permintaan pasar. 
Berdasarkan hasil optimasi dengan mempertimbangkan kendala luas lahan yang dimiliki, modal usaha yang tersedia dan alokasi ketersediaan tenaga kerja selama periode produksi serta daya serappasar maka diperoleh pola tanam yang optimal untuk diusahakan tanaman hortikultura adalah mengusahakan usahatani cabai seluas 0,71 hektar dan usahatani kacang panjang seluas 0,29 hektar. Dengan penerapan pola tanam yang optimal tersebut maka pendapatan petani dapat ditingkatkan sebesar 7,3\% dari pendapatan sebelumnya yaitu rata-rata Rp. 30.071.087 per hektar per periode tanam

\section{UCAPAN TERIMA KASIH}

Pada kesempatan ini penulis ingin menyampaikan terima kasih kepada Dekan dan Ketua Program Studi Agrinbisnis Fakultas Pertanian Universaitas Jambi yang telah memfasilitasi pelaksanaan penelitian ini. Selain itu ucapan terima kasih juga diucapkan untuk Kepala Desa Rantau Makmur dan Camat Berbak Kabupaten Tanjung Jabung Timur yang memfasilitasi pelaksanaan penelitian di lapangan.

\section{DAFTAR PUSTAKA}

Hernanto, F. 1996. IImu Usaha Tani. Penerbit Swadaya. Jakarta

Mulyono, Sri. 2007. Riset Operasi. Lembaga Penerbit Ekonomi Universitas Indonesia. Jakarta

Riduwan dan Akdon. 2009. Rumus dan Data dalam Analisis Statistik. Alfabeta:Cetakan Ke-3. Bandung

Setiawati, M. 2006. Analisis Optimasi Usahatani Terpadu di Kawasan Pengembangan Agropolitan Tanjung Jabung Timur. Skripsi Fakultas Pertanian Universitas Jambi

Setjanata, S. 1983. Perkembangan Penerapan Pola Tanam dan Pola Usahatani dalam Usaha Intensifikasi (Proyek Bimas). Lokakarya Teknologi dan Dampak Penelitian Pola Tanam dan Usahatani, Bogor, 20-21 Juni 1983. Pusat Penelitian dan Pengembangan Tanam

Soekartawi. 1987. Prinsip Dasar Ekonomi Pertanian Teori dan Aplikasi. Rajawali Pers. Jakarta

Suratiyah, Ken. 2009. Ilmu Usaha Tani. Penebar Swadaya. Jakarta

Walpole. 1995. Pengantar Statistik, Edisi 3. PT. Gramedia Pustaka Utama. Jakarta 